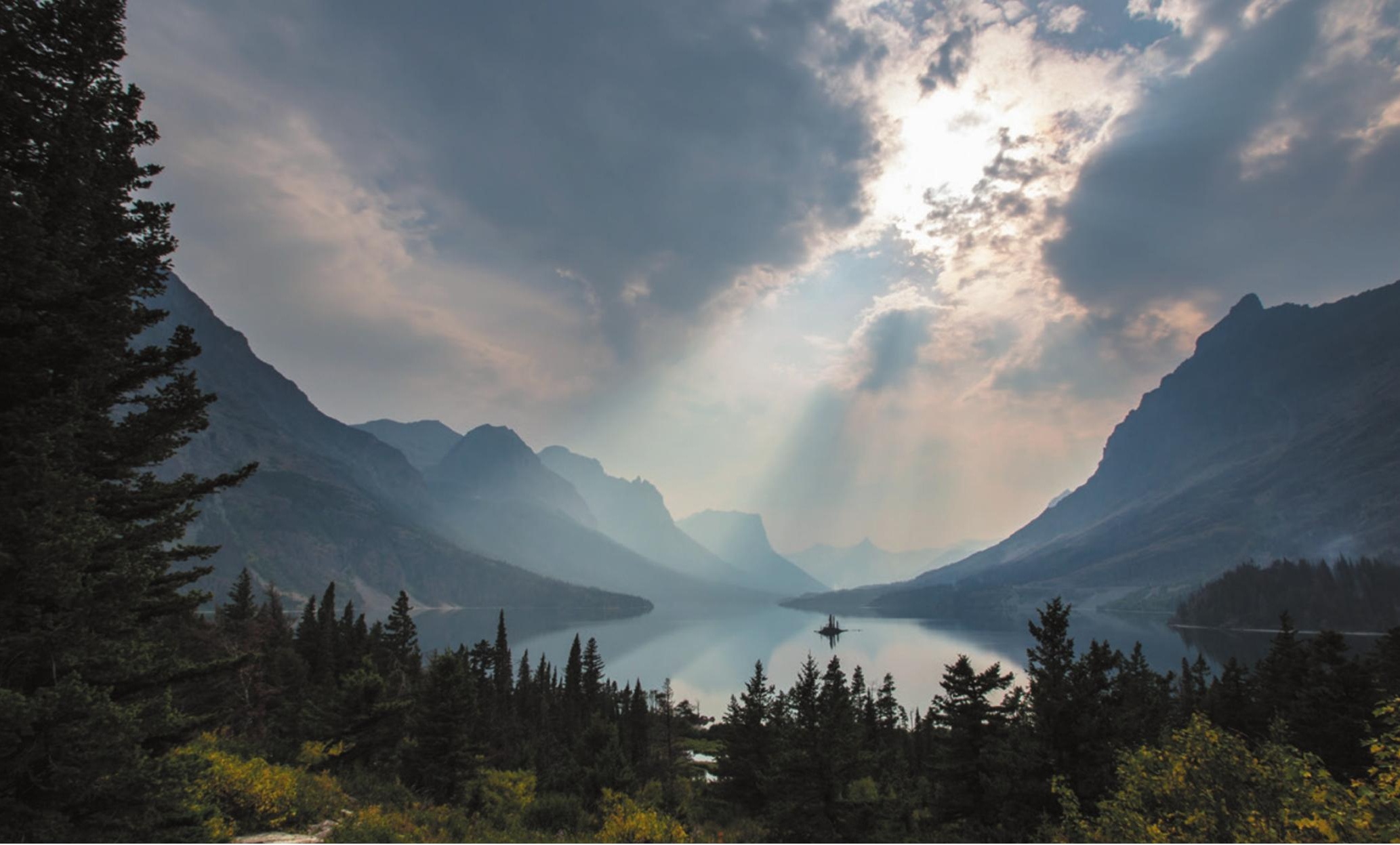

Glacier National Park in Montana is one of more than $\mathbf{4 0 0}$ sites administered by the US National Park Service, which turns 100 this year.

\title{
LISTINGS
}

\section{Science in culture 2016}

Gear up for some big birthdays, as anniversaries roll around for Star Trek, H. G. Wells and the US National Park Service. And jostling for the spotlight are Finding

Nemo's fishy crew, a modern twist on haute couture, groundbreaking artists, ground-quaking dinosaurs and (perhaps) Keanu Reeves. Daniel Cressey reports.

\author{
100 Years: The US National Park Service \\ On 25 August, the US National Park \\ Service (NPS) celebrates its centenary \\ -100 years since President Woodrow \\ Wilson signed it into existence, building \\ on the 1872 creation of Yellowstone \\ National Park by his predecessor \\ Ulysses S. Grant. The service, which \\ protects iconic landscapes from \\ California's Yosemite to the Florida \\ Everglades, is hosting events across \\ its 409 sites. Of course, the greatest \\ show of all, curated by nature itself, \\ runs 365 days a year in NPS parks, \\ from the Kïlauea and Mauna Loa \\ volcanoes on Hawaii's Big Island to the \\ 3,516-kilometre Appalachian Trail on \\ the US East Coast - the world's longest \\ footpath open only to hikers.
}

\section{Dinosaur extravaganza}

American Museum of Natural History, New York City Starting in January

New York gets a titanic new resident from 15 January, when the American Museum of Natural History installs a 37-metre-long cast of an as-yet-unnamed titanosaur. The bones of this giant herbivore, yet to be officially designated a species, were dug out of the Patagonian desert in Argentina. But that is just the start of the ancient-animal rollout. From March 2016 to January 2017, the exhibition Dinosaurs Among Us will explore how the titanosaur's relatives evolved to become birds: rare fossils and huge models will shed light on everything from birds' bones to dinosaur behaviour and brains. And from May 2016 to January 2017, Ancient Predators in a Modern World will tour 200 million years of crocodiles and their alligator, caiman and gharial relatives.
These remarkably specialized beasts are still recognizably the same as their ancestors that shared Earth with the dinosaurs.

\section{manus $x$ machina}

The Metropolitan Museum of Art, New York City 5 May - 14 August

The Costume Institute at New York's Metropolitan Museum of Art aims to show the world that there is more to high fashion than pouts and peplums: technology and style have been in symbiosis from the off. From an 1880s Worth gown to a 2015 Chanel suit, this show contrasts and draws parallels between the handmade marvel of haute couture (manus) and machine-produced clothing (machina). Do technologies such as laser cutting, ultrasonic welding or 3D printing stand up against intricate embroidery and hand-stitched linings? Strut in for a look. 


\section{Moholy-Nagy: Future Present}

Guggenheim Museum, New York

June-September

This major retrospective comes 70 years after the death of Hungarian industrial designer and radical artist László Moholy-Nagy, whose oeuvre spanned photography, abstract painting and metal sculpture. The artist founded a school of design in Chicago, Illinois, and died in the city in 1946. He was a key player in the German Bauhaus movement, embracing the transformative power of technology and mechanization in kinetic artworks (like his contemporary, Alexander Calder; see go.nature.com/n8rzsn). In the early 1920s, Moholy-Nagy experimented with outsourcing paintings by describing them in detail over the telephone to a painter in a sign factory, with the aid of colour charts and graph paper. The exhibition travels to Chicago and Los Angeles, California, after its New York run.

\section{Finding Dory}

Director: Andrew Stanton

Opens 17 June

Digital-animation giant Pixar releases the much-anticipated follow-up to its 2003 Finding Nemo, a film so successful that clownfish are now often referred to as 'nemos'. The original had marine biologists in raptures over its faithfulness to the science. Pixar has a mixed record when it comes to sequels, but if Finding Dory, featuring Nemo's Paracantharus friend (pictured), can combine the remarkable accuracy with the superb storytelling that the company is capable of, it could join Pixar's list of Oscarbotherers. Rumours suggest that the film was rewritten after the success of Blackfish, the 2013 documentary by director Gabriela Cowperthwaite that criticized the controversial keeping of killer whales in captivity.

\section{Engineering the World}

Victoria and Albert Museum, London

18 June - 6 November

Early in his career, engineer Ove Arup (1895-1988) worked on the floating Mulberry Harbours - temporary concrete breakwaters and piers set up for the Second World War Allied landing in Normandy on D-Day in 1944. He went on to help build iconic structures such as the Sydney Opera House, where his instincts for aesthetics and materials shone, before founding international mega-consultancy Arup, whose masterworks range from London's new research powerhouse, the Francis Crick Institute, to the Victoria and Albert Museum's own ongoing expansion plans. The exhibition promises to reveal Arup's multidisciplinary approach "as a humanistic and technological tool for social

\section{Years: Star Trek}

The world of Star Trek, first brought to television by US screenwriter Gene Roddenberry in 1966, inspires love in seemingly inverse proportion to the quality of its set design, special effects and (occasionally) acting. What keeps legion Trekkies passionate is the lingering glow of Roddenberry's delight in discovering "new life and new civilizations". Since the original show - with its then-radical multiethnic crew (some members pictured) - there have been another 4 live-action television series and 12 films, with fans from NASA leaders to schoolchildren. With the 13th film, Star Trek Beyond, due this year and a new television series promised in 2017, Star Trek remains the key science-fiction universe of modern times. (Sorry, Star Wars fans.)

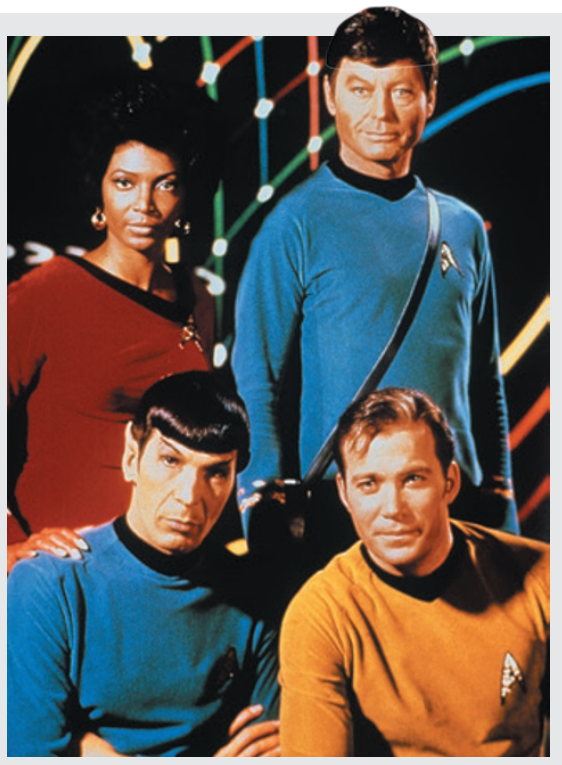

responsibility" and features prototypes, models and digital animations. It is part of the museum's Engineering the World exhibition, which will also include an installation by architect Achim Menges.

\section{Georgia O'Keeffe}

Tate Modern, London

6 July - 30 October

Visceral, often quasi-abstract evocations of botanical morphology in close-up paintings of irises and petunias helped to establish Georgia O'Keeffe's early career in 1920s New York. This retrospective at the Tate Modern will demonstrate the remarkable range of this groundbreaking modernist artist. In the late 1920s, O'Keeffe (pictured) moved figuratively and literally west to New Mexico, where the exposed, multicoloured topography inspired her to paint powerful landscapes and surreal studies that juxtaposed blossoms, bones, rocks and deadwood - paintings that in turn inspired others to re-examine the geology and biological riches of desert places.

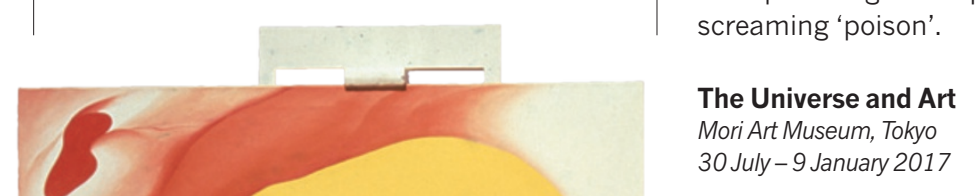

This exhibition asks how humans have viewed the Universe through millennia, starting with The Tale of the Bamboo Cutter - the oldest known piece of narrative prose in Japan, which dates back to the tenth century - and zipping forward to the age of the International Space Station and the search for alien life. Ranging from ancient art to contemporary astronomy, the show promises to explore how people through the ages have conceived of the vastness around them.

ANS (Autonomes NervenSystem) 12-16 July

The autonomic nervous system controls unconscious human bodily functions such musician Irini Amargianaki presents a multidimensional exploration of perception, incorporating instrumental pieces, video puppetry by Lisa Haucke. Premiering in Berlin as part of the Infecktion! festival for new

\section{Colour and Vision}

Natural History Museum, London

How did colours appear in the living world, and how did animals evolve the ability Natural History Museum will take viewers from the eyes of the beholder to the art and innovation that have emerged from nature's wild palette. Colour is crucial — from lights telling you to go or stop to tropical frogs that sport pigments

The Universe and Art

Mori Art Museum, Tokyo

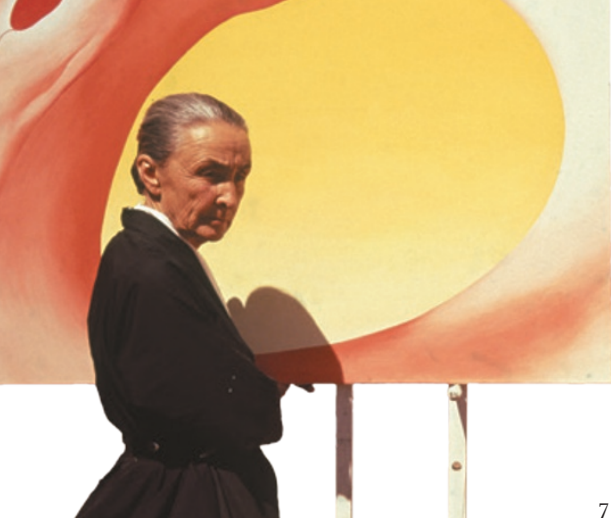

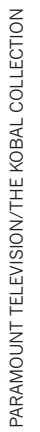




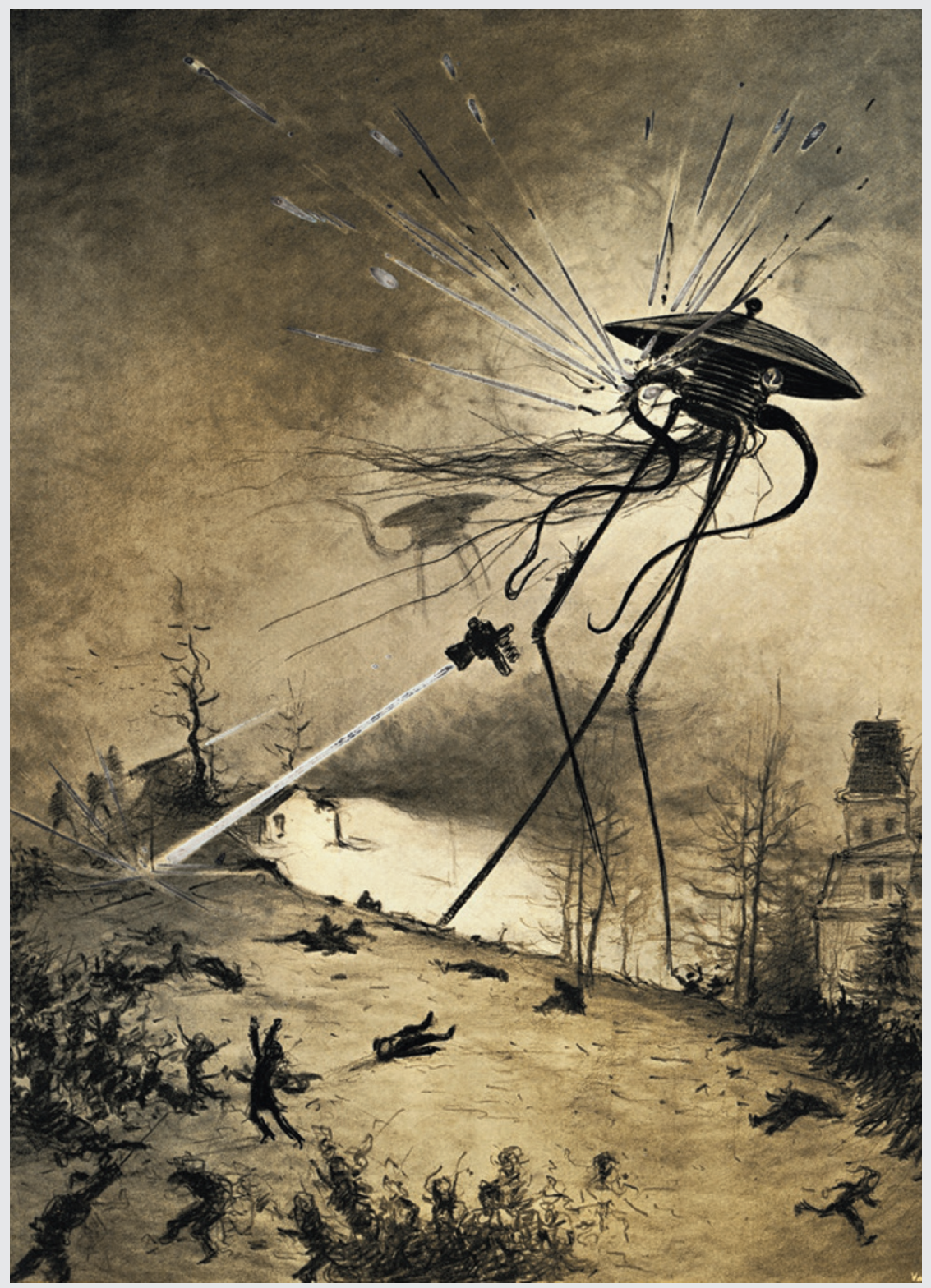

H. G. Wells (right) wrote more than 100 books, including science-fiction classic The War of the Worlds (top).

\section{Years: H. G. Wells}

This year sees two key dates focused on prescient author, scientist and educator H. G. Wells: the 150th anniversary of his birth, and the 70th of his death. Wells, who wrote more than 100 books, including The Time Machine (1895), The War of the Worlds (1898) and The Island of Doctor Moreau (1896), transformed turn-of-the-century science into literature that is still read, dissected and argued over today. Some of his short stories will be brought to life in a series of dramas airing on UK channel Sky Arts, and the H.G. Wells Society plans a programme of events (see go.nature.com/aasjbm).

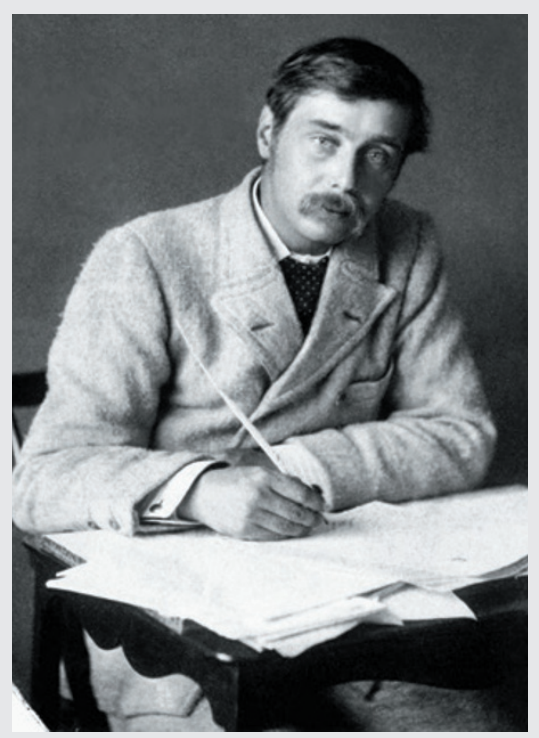

\section{Deepwater Horizon}

Director: Peter Berg

Opens 30 September

The 2010 Deepwater Horizon explosion and oil spill — which killed 11 people and spewed more than 3 billion barrels of crude oil into the Gulf of Mexico - was the worst environmental disaster in recent US history. Ecosystems and the regional economy suffered: wildlife died, beaches were shut and fisheries floundered. Now the events leading up to the disaster get the Hollywood treatment, as Mark Wahlberg takes on the role of an electronics technician on the doomed drilling rig. Expect gritty drama and courage in the face of adversity.

\section{Replicas}

Director: Tanya Wexler

Few details were available on this sciencefiction thriller as Nature went to press - not normally a good sign in a film. But reports that Keanu Reeves will play a neuroscientist who fights the government, police and the very laws of science to resurrect his family are intriguing.

\section{SEROND BHANBES}

\section{IF YOU MISSED THESE SHOWS THE FIRST TIME ROUND, THEY ARE NOW ON TOUR}

The Douanier Rousseau — Archaic Candour Musée d'Orsay, Paris 22 March - 17 July

Dozens of pieces by French post-Impressionist Henri Rousseau go on display at the Musee d'Orsay in Paris after a stint in Italy. They include stunning depictions of jungles, created by a man who never left France but regularly visited the botanical gardens of Paris.

\section{Leonardo da Vinci: The Mechanics of Genius Science Museum, London 10 February - 4 September \\ Who needs the Mona Lisa when you can have a flying machine? This touring exhibition of ingenious models brings to life the mechanical contraptions sketched out by history's greatest polymath.}

\section{Strandbeest: The Dream Machines of Theo Jansen}

Exploratorium, San Francisco, California 27 May - 5 September

Arriving in California in May, far from their birthplace on the Dutch coast, are the vast, surreal-looking Strandbeest ('beach beast') automatons created by artist Theo Jansen. These mechanical animals move on gusts of wind and have amazed viewers with their strange dances, at once robotic and naturalistic. 